\title{
To Help or Not to Help? Factors that Determined Helping Responses to Katrina Victims
}

\author{
Tatyana V. Avdeyeva* \\ University of St. Thomas
}

\section{Kristina Burgetova}

University of St. Thomas

\section{David Welch \\ University of St. Thomas}

Major research findings regarding individual helping behavior are reviewed and analyzed in light of the events during and after Hurricane Katrina. Implications from traditional and contemporary theories of psychology are examined. The discussion addresses both intrapersonal and contextual (psychosocial and situational) factors related to individual helping behavior in the context of real world events around the hurricane. In addition, the article contains implications for public policy and suggestions for policy makers.

One year has passed since the hurricane described as "the biggest natural catastrophe of our lifetime" (Steuer, 2006, p. 11) devastated American Gulf States. Katrina brought "a significant loss of life, extensive or total destruction of property, disruption of lifeline services, and the sources of livelihood" (Dynes \& Rodriguez, 2006, para. 3). The damage from this hurricane has already cost the country over $\$ 81.2$ billion (Wikipedia, n.d.). Taking into consideration that before the hurricane the region held 1 million nonfarm jobs, of which 600,000 were localized in New Orleans, the total economic impact to the affected states is estimated to be more than $\$ 200$ billion (Donlan, 2006). It is now believed that the total death numbers have reached 1,836; an additional 1,840 persons are still considered missing (Wikipedia, n.d.).

\footnotetext{
* Correspondence concerning this article should be addressed to Tatyana V. Avdeyeva, 1000 LaSalle Ave., TMH 451, Minneapolis, MN 55403 [e-mail: tavdeyeva@stthomas.edu].
} 
The New York Times investigated deaths of 260 Louisianans and concluded that almost all of these victims survived the height of the storm but died in the chaos and flooding that followed. "More than 100 of them drowned. Sixteen died trapped in attics. More than 40 died of heart failure or respiratory problems, including running out of oxygen. At least 65 died because help—-shelter, water, or a simple dose of insulin — came too late" (Dewan \& Roberts, 2005, p. 46). Most victims were elderly, and many were ill or disabled. While fingers could be pointed at the federal and state agencies responsible for providing the necessary aid, one could also ask if neighbors and passers-by were aware of the unfolding tragedy and whether they did their share to prevent the deaths of these 260 people. Can we as humans rely on each other when our governments fail to provide aid? Although some polls suggest that $77 \%$ of Americans want to help those affected in times of disaster (Marchetti \& Bunte, 2006), extant research suggests that it is an intricate interplay of intrapersonal, psychosocial, and situational factors that determines whether the actual helping behavior takes place.

\section{Intrapersonal Factors That Impact Helping Behavior}

Traditional theories of psychology have not described human personality as generally helpful. Freud and other psychoanalytic theorists viewed individual behavior as motivated by self-interest and aggression (Deaux, Dane, \& Wrightsman, 1993), leaving little room for understanding of helping behavior. Behaviorists have provided a clearer framework to explain helping, but only in terms of a "give and take" exchange, whereby people are seen as capable of helping only if they can expect some sort of reinforcement, such as praise, recognition, or more subtle rewards (Gelfand \& Hartmann, 1982). These rewards are not limited to external reinforcement, but they can come from within an individual, for example, by experiencing an increase in self-liking, pride, or a sense of accomplishment. Sociobiological theories also view helping behavior as ultimately selfish, in that it is motivated by passing on as much of a genetic formula as possible (Barret, Dunbar, \& Lycett, 2002). This view explains why we help our kin, but also suggests that we are more likely to help those who are genetically similar to us.

The implication of these basic theories of psychology is that human personality is not designed to offer internal motivation for helping unless it is somehow beneficial to a potential helper. According to these theories, when faced with lifethreatening events, human beings, motivated mostly by their own interests, are likely to focus on their own survival and, at most, on the survival of their kin. Thus, unless the elderly and ill Louisianans were connected to friends or family, their chances of receiving help during and immediately after Katrina were sadly low. While there is no doubt that many of the stronger and healthier victims of the disaster would have been available to help under normal conditions of safety and security, during the hurricane, these potential helpers may have had little psychological and material resources to spare for someone else in need. 
As noted above, behavioral theories predict that a cost-benefit analysis is likely to take place in any help-evoking situation, and for most people, helping action is undertaken only if perceived benefits outweigh potential costs associated with helping. This approach sheds some light on why donating became a helping response of choice for much of the American public. If it is true that for helping behavior to occur, its gains must exceed its costs, most people would choose a method that is low in risk, time, and energy but at the same time provides internal gratification, such as expression of empathy, relief of frustration, and increase in self-pride. Writing a check appears optimal in this sense. Indeed, donations to Katrina victims were so widespread that the American Red Cross alone has collected an unprecedented $\$ 2.116$ billion during the five months after the hurricane, and by February 2006, this agency announced that it had accumulated sufficient funds to cover its expenses for all 2005 hurricanes (Red Cross Press Release, 2006).

And yet, numerous people chose to do more than write a check. Many responded with offers to make long-distance telephone calls, to run errands, to share frequent-flier miles, and to give cars; others offered to stable abandoned cattle, to share accommodations, and even to provide jobs and salaries (Manners, 2005). The research by Batson and his colleagues (e.g., Batson, Duncan, Ackerman, Buckley, $\&$ Birch, 1981) points at the role of empathy in motivating helping behavior. A series of experiments showed that for a certain number of people, a desire to relieve the others' suffering was sufficient to elicit a helping response, even if helping was associated with potential harm to themselves. Although some researchers have questioned whether altruistic helping is driven by empathy or a more selfish desire to relieve one's own frustration at seeing another suffer (e.g., Neuberg, Cialdini, Brown, Luce, Saragin, \& Lewis, 1997), the role of empathy has been supported by further research (e.g., Batson \& Shaw, 1991). Steuer (2006) has interviewed 20 psychologists from California who had rushed to the South immediately after Katrina hit. She concludes that most of these people reported "feeling impelled" and that there was "no logic to it" (Steuer, 2006, p. 11), suggesting that empathic feeling did play an important role in their choice to invest considerable amount of time and energy to help Katrina victims. However, Steuer (2006) notes that for many of her respondents, the shortened period of this commitment ( 9 days instead of the usual 14) also played a role in their decision to help, indicating that some cost-benefit analysis took place.

Whether or not helping is driven by pure desire to relieve another's pain or by more egotistical forces, the fact is that, at least for some individuals, a desire to help another human being was strong enough to risk their own physical well being. Consider this excerpt from an eye-witness account in New Orleans:

What ... we saw first-hand, were the real heroes of the hurricane relief effort: the working class of New Orleans. The maintenance workers using fork lifts to carry the sick and disabled. The engineers who rigged, nurtured and kept generators running. Electricians who improvised thick extension cords stretching over blocks to share the little electricity we had to free cars on rooftop lots. Nurses who took over for mechanical ventilators and 
spent many hours on end manually forcing air into the lungs of unconscious patients to keep them alive. Doormen who rescued folks stuck in elevators. Refinery workers who broke into boat yards, "stealing" boats to rescue their neighbors clinging to their roofs in flood waters. Mechanics who helped hot-wire any car that could be found to ferry people out of the city. And the food service workers who scoured the commercial kitchens improvising communal meals for hundreds of those stranded. Most of these people had lost their homes and had not heard from members of their families, yet they stayed and provided the only infrastructure for the $20 \%$ of New Orleans that was not underwater (Sheppard, 2006).

In addition to empathy-altruism hypothesis, another model that provides an explanation of self-sacrificial helping is the study of specific personality characteristics that predispose a person to respond positively to the need for help. The focus of this approach is on altruistic personality, which presumes such attributes as altruistic disposition, other-oriented concern, social responsibility, perspective taking (Gustavo, Eisenberg, Troyer, Switzer, \& Speer, 1991), and agreeableness (Graziano \& Eisenberg, 1997). Eisenberg et al. (2002) have provided evidence of stability of prosocial disposition across five years, which points at its trait-like nature. Altruistic personality has been directly linked to helping behavior (Eisenberg et al., 1989). According to Batson (1987), altruistic persons are more likely to help even when the escape from the situation is easy. However, Eisenberg (1986) has pointed out that altruistic individuals might be expected to help more than others only if the help-seeker clearly appears to be in need or distressed. In other words, the message about a need for help must be very clear. Unfortunately, what this means for those elderly and disabled who did not (could not?) make it out into the streets or had put on "a brave face" is that they were exposed to even higher risk of being left behind.

Researchers also examined the role of other, nonaltruistic personality characteristics in helping behavior. Gustavo et al. (1991), for example, hypothesized that general emotional reactivity as well as concern with social desirability may contribute to helping behavior. Through experimental manipulations and a series of statistical analyses, they found that trait emotional arousability was significantly and positively related to helping in low-evocative easy-escape conditions. That is, people who tend to be easily aroused are more likely to respond even when they can avoid the situation and when the victim's problem is relatively benign. Furthermore, Gustavo et al. (1991) found that high scores on social desirability were associated with more helping only in the low-evocative, difficult-escape condition, that is, people who are highly concerned with self-image and the social desirability of their actions tend to help even if the situation is not particularly distressing, but only when it is difficult to escape. When there is an easy escape from an opportunity to help, such individuals may exhibit no more helping behavior than others. We can hypothesize then, that in the extreme circumstances, such as during the flood following Katrina, the propensity to regulate self-image in a socially desirable manner affected the amount and quality of helping behavior. Persons who were highly concerned with presenting themselves as prosocial were 
not necessarily the ones who helped the most because they had plenty of excuses to avoid helping (for example, an understandable need to flee the area to save their own lives or property).

\section{Contextual Factors}

Besides being motivated by intrapersonal variables, helping behavior depends highly on the context in which helping behavior is being evoked. Throughout the years, researchers have identified a number of contextual factors influencing helping behavior. We broadly divide them in two categories: (1) psychosocial variables and (2) situational variables.

\section{Psychosocial Variables}

The relationship of an individual to a community in which a help-evoking situation occurs directly contributes to the motivation to help. As explained by sociobiological perspective, we are more likely to help our kin, friends, and even brief acquaintances (Pearce, 1980). Furthermore, people who are better integrated and involved in their communities are more likely to engage in helping their community members (Penner, Dovidio, Piliavin, \& Schroeder, 2005) and have received more help from others through social support networks during the Katrina (Hurlbert, Beggs, \& Haines, 2006). Also, individuals who experience themselves as part of an interconnected collective may be more likely to help their fellow community members in a planned and sustained fashion such as by volunteering (Penner et al., 2005). These findings help explain why ethnic minorities have traditionally volunteered less than Caucasians in charity organizations (Penner et al., 2005) and suggest that low acculturation to a mainstream society and high retention of native cultural membership may decrease participation in a more diffuse form of helping (e.g., volunteering for a large organization) but may augment direct helping behavior toward members of the in-group. Some reports from the South do suggest that during and posthurricane, culturally isolated communities, such as immigrants from highly collectivistic cultures (e.g., Vietnamese), were extremely helpful toward each other (e.g., Block, 2005). In a related vein, information obtained from the leaders of different chapters of United Way (personal communication, McGrew, D., Rose, A., October 2005), indicates that in their agencies, the majority of volunteers were White.

Furthermore, lack of contact between groups (e.g., segregation based on class and/or ethnicity) is known to be associated negatively with between-group helping behavior and positively with group bias (Axelrod, 1984; Gaertner et al., 1999). This raises the issue of ethnic composition of the helping dyad and the effects of race on helping behavior. Most of the extant research on interaction between ethnicity and helping behavior dates back to the 1970s and is inconsistent, with 
some authors documenting less cross-racial helping and others documenting more (e.g., Katz, Cohen, \& Glass, 1975; Thayer, 1973; Wegner and Crano, 1975). Katz (1981) described Whites' attitudes toward Blacks as ambivalent: they want to be sympathetic and unprejudiced and yet experience some negative feelings toward Black people. Frey and Gaertner (1986) found that Whites helped Blacks less quickly than they did other Whites when the situation was ambiguous, but the speed of response was the same when the situation was unambiguous. Deaux et al. (1993) pointed out that Whites are most helpful when a failure to help would clearly mark them as bigots and are less likely to help when their behavior is easily justifiable by other reasons. Today, some researchers believe that White Americans still do not fully accept African Americans (e.g., Molotch, 2006).

After Hurricane Katrina, much discussion took place on interracial factors that affected the way hurricane victims were treated. Although the American government denied that there was any racial component to people being left behind, many critics suggested that the response would have been quicker had the victims been predominantly White (e.g., Kaufman, 2006; Krause, 2006; Ross, 2005). Potok (2005) reports that the hurricane crisis activated open racial hatred among some of the right-wing Whites as well as, albeit rare, racial exclusivity related to helping (e.g., Internet-posted offers to help "Whites only"). While statistics regarding individual interracial helping are not available, eye-witness accounts have pointed at the widespread perception that race may have become a real barrier encountered by many minority victims. Consider this example recounted by two White, middle-aged, middle-class paramedics trapped in New Orleans after attending a professional conference and trying to escape the city with a group of mostly Black residents:

\footnotetext{
We organized ourselves and 200 of us set off for the bridge with great excitement and hope. As we approached the bridge, armed Gretna sheriffs formed a line across the foot of the bridge. Before we were close enough to speak, they began firing their weapons over our heads. ....A few of us inched forward and managed to engage some of the sheriffs in conversation... . They responded that the West Bank was not going to become New Orleans and there would be no Superdomes in their city. These were code words for "if you are poor or black, you are not crossing the Mississippi river (Sheppard, 2006).
}

When that sheriff was questioned later, he did confirm that he had closed the bridge, explaining that his parish (Jefferson Parrish) did not have adequate resources to provide help to the numerous victims from the other side of the city (Kaufman, 2006). Jefferson Parish is $78 \%$ White, while the crowd from New Orleans was mostly Black, which together with using "code words" as an expression of modern racism (Kaufman, 2006), point to the fact that race (and likely class) did become a real consideration in his decision not to help the pleading crowd. Gillman (2006) has observed that such actions were not necessarily an expression of conscious discrimination but a result of deep social and institutional practices and habits of social isolation and exclusion. This historic divide may have 
diffused empathy by creating a perception that the victims were a threat rather than people in need (Krause, 2006). Similarly, Molotch (2006) has suggested that race became a decisive factor in failure to provide help to Katrina's minority victims by inhibiting empathy for them or by weakening the assumption that others shared circumstances with them.

The most recent data from Louisiana indicate that the majority of Katrina fatalities there were African American. According to the Louisiana Department of Health and Hospitals (2006), 451 (53\%) deaths were African American, 334 (39\%) Caucasian, 18 Hispanic $(2 \%), 4(<1 \%)$ Native American, and $6(<1 \%)$ Asian/Pacific. Proportionally, however, the death toll among Caucasians was higher than that of other ethnic groups, considering that they constituted only $28 \%$ of residents in such hard-hit areas as New Orleans.

While it is likely that, as a group, weak and elderly of all races were most dependent on other people's help (indeed, 70\% of deaths in Louisiana were among those 60 and older), research on social norms provides a hypothesis as to why White Louisianans died at a somewhat higher rate than their minority counterparts. Social norms exert great social power and can facilitate or attenuate a motivation to help because, if internalized, they become an integral part of one's self-concept, so that the future normative or nonnormative behavior represents conforming to one's own expectations of self, leading to either a feeling of self-esteem or self-disapproval (Cialdini \& Trost, 1998). In an individualistic mainstream White American society, social norms emphasize the values of autonomy and self-reliance. The basic belief is that one is in control of one's own destiny (Sue \& Sue, 1990), making it difficult not only to ask for help but also to offer unsolicited help because it may potentially undermine another person's self-view as a self-sufficient human being. Minority cultures, such as African-American culture, in contrast have been described as group centered, sensitive to interpersonal matters, and valuing cooperation (Sue $\&$ Sue, 1990). Thus, minority elderly and weak are more likely to function in an interdependent mode, whereby taking care of each other is a norm. In a time of an unprecedented natural calamity, with most individuals unable to accurately gauge either the extent of the upcoming crisis or their ability to cope, elderly White persons may have been more likely to express their self-reliance by staying at home and trying to persevere through the storm on their own. They may have been less likely to ask for help, believing that it may turn them into the subjects of unwanted dependence, or could be more likely to take chances because of the belief that they "can do it" on their own.

Another finding of research on norms is that the norm of reciprocity may exert more influence in an individualistic cultural context. Perlow and Weeks (2002) have compared American and Indian helping behavior in an organization. They have found that Americans tend to provide help only to those from whom they expect to seek help in the future, while employees in India are likely to assist whoever needs help. The unfortunate implication is that the most helpless victims of the hurricane, 
such as the isolated elderly, ill, and disabled, were the most disadvantaged in terms of being selected as help objects, in that there is little that they could return for being helped.

Fortunately, individuals who have internalized another social norm, that of social responsibility (i.e., a belief that one should help another in need), are likely to extend help even if there is nothing to expect back from the victim (e.g., Schwarts \& Howard, 1981). Because the norm of social responsibility is emphasized by most religious teachings, religious groups typically provide help to disadvantaged people and substantially expanded their efforts during the hurricane (Rodriguez, Trainor, \& Quarantelli, 2006). For example, parishioners from St. William Catholic Church on St. Thomas Island in Georgia had taken several trips during September 2005 and April 2006 to the Gulf Coast to assist hurricane victims (Horn, 2006). During these trips, volunteers often stayed at other parishioners' homes, and together they dedicated their time and worked on demands received by Catholic Charities (e.g., converting a skating rink to a church and a school, cleaning out damaged homes, providing and delivering supplies).

\section{Situational Factors}

Besides intrapersonal and group processes, the specific situation provides further parameters of helping behavior. First, as Krebs and Miller (1985) point out, the victim is more likely to be helped when the need is clear and unambiguous. Some of the most helpless victims of the disaster-animals-received help from the American public that was unprecedented in size and speed of response. The Humane Society of the United States received \$15 million in donations within two weeks after the hurricane had occurred (Wikipedia, n.d.). Sadly, the need for help by many elderly and sick human beings was not apparent until it was too late.

The legitimacy of the call for help also influences the outcome of help-seeking, that is, if requests for help are not perceived as legitimate, help is less likely to be granted. In addition, the perceived cause of a problem appears to play a role in the amount of extended help. Specifically, if the reason for a victim's suffering is attributed to external and uncontrollable factors (e.g., a hurricane), people are more likely to help. If, on the other hand, the cause of a problem is explained by internal and controllable factors, such as the perceived choice not to evacuate before the hurricane - a belief that was not uncommon within the American public (Fussell, 2006) — the likelihood of help is diminished. Betancourt (1990) pointed out that people are more likely to feel anger rather than compassion toward a person whom they see as responsible for the problem (e.g., a decision not to evacuate before the hurricane), and this emotional reaction mediates their decision making regarding whether or not to help.

Behavior of other people in a given situation also affects helping behavior. For instance, bystander apathy effect is generally regarded as an established 
phenomenon (Garcia, Weaver, Moscovitz, \& Darley, 2002). When a person is in need of help, his/her chances of being helped are inversely related to the number of people present. In a recent study, Garcia et al. (2002) found that as little as imagining oneself as being with a group of people diminishes helping behavior on a subsequent unrelated task. What is the implication of the bystander apathy hypothesis to a large-scale emergency like Katrina? If it is true that the more people are perceived to be around, the less helping an individual is likely to display, then extreme situations, such as national calamities, will be the least likely to arouse helping behavior in individuals. Indeed, if the public perception is that not only is the whole country involved in helping, but also numerous organizations, individual help giving may reach a minimum. Luckily, psychological research does show that as people become aware that others (whether real or imagined) cannot help, they will behave as if alone and bystander apathy will not occur (Bickman, 1972). Thus, people are likely to initiate helping once it becomes clear that victims are not being adequately helped.

\section{Summary and Implications for Public Policy}

In any help-evoking situation, intrapersonal, psychosocial, and situational factors combine in unique and complex ways that can lead a person to either extend help or to abstain from helping. Katrina has demonstrated that, as predicted by psychological theories, the American public in general responded empathically to hurricane victims, and numerous people engaged in many forms of helping. The responses varied widely and included personally safe and limited forms of helping, such as donating, as well as more costly and self-sacrificial ways to help that ranged from volunteering at a far-from-home disaster location to acting heroically by risking one's life.

Despite the widely spread helping efforts, Katrina's death toll was high. Faced with devastating natural force and lack of efficient government aid, a high number of elderly, sick, and disabled had to rely on help from other people. Many of them received a helping hand. But for others, such factors as a high perceived cost of helping them, lack of familial or cultural support networks, failure to make their needs known, and perhaps a misfortune of not coming across an altruistic person, combined to result in injury and death. Important lessons must be drawn from this experience in order to prevent similar outcomes in the future.

At the macro level, much work needs to be done on improving organization and efficiency of helping organizations, as well as communication between various government structures. Because aid agencies depend on help from individuals (e.g., through financial support or volunteer participation), and also because law enforcement, military, and emergency management agencies rely on public cooperation to successfully accomplish their mission, understanding of individual 
helping behavior is relevant to development and implementation of effective public policy related to crises.

Psychological research reviewed in this article demonstrates that a broad expectation that individuals will help each other in an emergency situation may be unrealistic. Typical bystanders are likely to engage in helping if they perceive it as low risk and beneficial personally. Therefore, it is important that leadership and personnel of aid agencies involved have a clear understanding of their role and responsibilities, and they must strive to be as self-sufficient and self-reliant as possible. At the same time, the general public needs to gain increased awareness of its responsibility as well and to take full advantage of traditional, indigenous, and social coping mechanisms of specific communities (Alexander, 2006).

Ill, disabled, and elderly people faced some of the most severe horrors of Katrina, and many were simply left to die (Frymer, Strolovitch, \& Warren, 2006). Needs of this particularly vulnerable segment of population must be better addressed, and this can be accomplished by establishing specific procedures for helping these individuals. Work in this direction has already started. Consider guidelines for the next hurricane from the Louisiana Department of Health and Hospitals:

\footnotetext{
In the event of a hurricane, the Department of Health and Hospitals will publish regional triage telephone numbers for each area of the state. Citizens with special needs must call the number for their area to access a special needs shelter. Special Needs Shelters are for individuals with health problems that require medical expertise. They are not designed for the general public or for nursing home patients. Because of limited staffing, those going to a Special Needs Shelter must have a caretaker to assist with ongoing support and they should bring all necessary supplies including sheets, blankets and pillows.
}

While such guidelines are surely meant to be useful and may be a good start, there are several potential problems for those elderly and ill who do not qualify as "special needs" patients or who do not have access to "a caretaker to assist with ongoing support." What are they to do and where can they seek help? More work needs to be done by government agencies in order to establish procedures that would enable all at-risk persons to obtain necessary resources in the next crisis. In the meantime, local communities, including formal and informal neighborhood organizations, need to become involved in preparing to extend help during the next disaster.

One way to do it is by developing programs (similar to Neighborhood Watch, for example), that would contain specific steps for those willing to provide help to the most vulnerable members of a given community. Rodriguez et al. (2006) have described how in many hurricane-afflicted areas prosocial behavior emerged in a form of neighborhood groups that took initiative for rescue and shelter of other community members. In New Orleans one such group, "The Robin Hood Looters," spent two weeks searching for the survivors of their working-class neighborhood; another group gathered neighbors in a school on high ground, where canned 
food, cleaning supplies, and radios were stored. By organizing such groups before rather than after a potential disaster, local communities can add substantially to government-led rescue efforts, while the government agencies (e.g., police) can benefit from establishing collaborative relationships with such groups in order to benefit from their assistance and reduce their, albeit occasionally, illegal nature (Rodriguez et al., 2006).

Furthermore, intentional and funded efforts need to be undertaken in order to bring the norm of social responsibility, as well as the reality of social interdependence in times of crisis (as opposed to a more common assumption based on the American value of independence), closer to the societal consciousness. Educational and media campaigns focused on promotion of the norm of social responsibility, sense of community, and human kindness can be effective in increasing the salience of this norm at the individual level.

In any help-evoking situation, there are people who exhibit extraordinary efforts to help reduce the suffering of others. Not only is their work critical in itself, but it also models kindness and altruism for others. If we are to respond more effectively to the victims of the next disaster, which will sooner or later arise, we need to actively promote helping behavior. Media and educational campaigns may need to focus on altruistic persons specifically (they are most likely to respond to them positively by virtue of their personalities), but a general population should be targeted as well, so that the prestige associated with helping and the public awareness of concrete gains from being helpful is increased. So far, it appears that heroic acts are recognized randomly. Some heroes make it to television and may even receive an award from the government; many other helping acts go unnoticed. Public policy aimed at developing and implementing effective mechanisms to publicly recognize and meaningfully reward heroes seems vital in this respect.

The role of media in promoting helping behavior cannot be overestimated. By promoting prosocial norms, recognizing individual altruistic behavior, raising awareness of inequality and segregation, delivering clear messages about a need for help, and emphasizing values of interdependence and cooperation, media has a unique power to facilitate helping behavior on a mass level.

The problems of inter-class and inter-ethnic relations became very apparent during the Katrina crisis. The extant research predicts mediating effects of ingroup/out-group perceptions on helping. However, most research on these issues is somewhat outdated. Through providing funds for further research and by encouraging social campaigns and educational programs aimed at increasing public awareness and acceptance of diversity and common American identity, policy makers are in power to make meaningful changes.

Overall, as Lakoff (2006) pointed out, "the hurricane and its aftermath could be said to have a shared moral, it is this: we are not prepared" (para. 2). As the policy makers work on improving the system to respond better to the next 
disaster, be it a terrorist attack or some type of natural disaster, the findings on human helping behavior should be taken into account. Psychological literature as well as post-Katrina reports suggest that although not omnipresent, helping behavior is a real phenomenon that can make a life and death difference in times and situations when government assistance is not available. By capitalizing on intrapersonal, psychosocial, and situational factors that help promote helping, much can be accomplished to supplement rescue and aid operations in the future.

\section{References}

Alexander, D. (2006). Symbolic and practical interpretations of the Hurricane Katrina disaster in New Orleans. Understanding Katrina: Perspectives from the Social Sciences, the Forum of the Social Science Research Council. Retrieved July 14, 2006 from http://understandingkatrina.ssrc.org/ Alexander/

American Red Cross. (2006). Generous Donors Meet American Red Cross Hurricane Relief Costs: Red Cross Honors Commitment to Donors and Public. Retrieved July 11, 2006 from http:// www.redcross.org/pressrelease/0,1077,0_273_5090,00.html

Axelrod, R. (1984). The evolution of cooperation. New York: Basic Books.

Barret, L., Dunbar, R., \& Lycett, J. (2002). Human evolutionary psychology. Princeton, NJ: Princeton University Press.

Batson, C. D. (1987). Prosocial motivation: Is it very truly altruistic? In L. Berkowitz (Ed.), Advances in experimental social psychology (Vol. 20, pp. 65-122). San Diego, CA: Academic Press.

Batson, C. D., Shaw, L. L. (1991). Evidence for altruism: Toward a pluralism of prosocial motives. Psychological Inquiry, 2, 107-122.

Batson, C. D., Duncan, B. D., Ackerman, P., Buckley, T., \& Birch, K. (1981). Is empathic emotion a source of altruistic motivation? Journal of Personality and Social Psychology, 40, 290-302.

Betancourt, H. (1990). An attribution-empathy model of helping behavior: Behavioral interventions and judgments of help-giving. Personality and Social Psychology Bulletin, 16, 573-591.

Bickman, L. (1972). Social influence and diffusion of responsibility in an emergency. Journal of Experimental Social Psychology, 8, 438-445.

Block, D. (2005). Vietnamese-American Katrina Victims pull together, Baton Rouge. Retrieved May 31, 2006 from http:// voanews.com/english/archive/2005-09/2005-09-26-voa53.cfm

Cialdini, R. B., Trost, M. R. (1998). Social influence: Social norms, conformity, and compliance. In D. T. Gilbert, S. T. Fiske, G. Lindzey (Eds.), The handbook of social psychology (pp. 151-192). Boston, MA: The McGraw-Hill Companies, Inc.

Cialdini, R. B., Schaller, M., Houlihan, D., Arps, K., Fultz, \& Beaman, A. L. (1987). Empathy-based helping: Is it selflessly or selfishly motivated? Journal of Personality and Social Psychology, 52, 749-758.

Cunningham, M. R., Steinberg, J., \& Grev, R. (1980). Wanting to and having to help: Separate motivations for positive mood and guilt-induced helping. Journal of Personality and Social Psychology, 38, 181-192.

Deaux, K., Dane, F. C., \& Wrightsman, L. S. (1993). Social psychology in the 90's. Pacific Grove, CA: Brooks/Cole Publishing Company.

Dewan, S., \& Roberts, J. (2005, December 18). Louisiana's deadly storm took strong as well as the helpless. New York Times, pp. 46.

Donlan, T. S. (2006, July 31). Controlling the cash flood: A natural catastrophe does not have to be a financial disaster. Barron's: A Dow Jones Business and Financial Weekly, pp. 11.

Dynes, R. R., \& Rodriguez, H. (2006). Finding and framing Katrina: The social construction of disaster. Understanding Katrina: Perspectives from the Social Sciences, the Forum of the Social Science Research Council. Retrieved July 14, 2006 from http://understandingkatrina.ssrc.org/ Dynes_Rodriguez/ 
Eisenberg, N. (1986). Altruistic emotion, cognition, and behavior. Hillsdale, NJ: Erlbaum.

Eisenberg, N., Miller, P. A., Schaller, M., Fabes, R. A., Fultz, J., Shell, R., \& Shea, C. L. (1989). The role of empathy and altruistic personality traits in helping: A reexamination. Journal of Personality, 67, 41-67.

Eisenberg, N., Guthrie, I. K., Cumberland, A., Murphy B. C., Shepard S. A., Zhou, Q., Gustavo, C. (2002). Prosocial development in early adulthood: A longitudinal study. Journal of Personality and Social Psychology, 82, 993-1006.

Frey, D. L., \& Gaertner, S. L. (1986). Helping and the avoidance of inappropriate interracial behavior: A strategy that perpetuates a nonprejudiced self-image. Journal of Personality and Social Psychology, 50, 1083-1090.

Frymer, P., Strolovitch, D. Z., \& Warren, D. T. (2006). Katrina's political roots and divisions: Race, class, and federalism in American politics. Understanding Katrina: Perspectives from the Social Sciences, the Forum of the Social Science Research Council. Retrieved July 14, 2006 from http://understandingkatrina.ssrc.org/FrymerStrolovitchWarren.

Fussell, E. (2006). Leaving New Orleans: Social stratification, networks, and hurricane evacuation. Understanding Katrina: Perspectives from the Social Sciences, the Forum of the Social Science Research Council. Retrieved July 14, 2006 from http://understandingkatrina.ssrc.org/Fussell/

Gaertner, S. L., Rust, M. C., Mottola, G. R., Dovidio, J. F., Nier, J. A., Banker, B. S., Ward, C. M. \& Houlette, M. (1999). Reducing intergroup bias: Elements of Intergroup Cooperation. Journal of Personality and Social Psychology, 76, 388-402.

Garcia, S. M., Weaver, K., Moscowitz, G. B., \& Darley, J. M. (2002). Journal of Personality and Social Psychology, 83, 843-853.

Gelfand, D. M., \& Hartmann, D. P. (1982). Response consequences and attributions: Two contributors to prosocial behavior. In N. Eisenberg (Ed.), The development of prosocial behavior, 167-198. New York: Academic Press

Gilman, N. (2006). What Katrina teaches about the meaning of racism. Understanding Katrina: Perspectives from the Social Sciences, the Forum of the Social Science Research Council. Retrieved July 14, 2006 from http://understandingkatrina.ssrc.org/Gilman/

Graziano, W. G., \& Eisenberg, N. (1997). Agreeableness: A dimension of personality. In S. Briggs, R. Hogan, \& W. Jones (Eds.), Handbook of personality psychology (pp. 795-824). San Diego: Academic Press.

Gustavo, C., Eisenberg, N., Troyer, D., Switzer, G., \& Speer, A. L. (1991). The altruistic personality: In what contexts is it apparent? Journal of Personality and Social Psychology, 61, 450-458.

Horn, B. (2006). Ongoing Katrina volunteer activity: St. William Catholic Church. Retrieved May 21, 2006 from http://stwill.net/outreachministries/article-1999918619c-1998949272.htm

Hurlbert, J. S., Beggs, J. J., \& Haines, V. A. (2006). Bridges over troubled waters: What are the optimal networks for Katrina's victims? Understanding Katrina: Perspectives from the Social Sciences, the Forum of the Social Science Research Council. Retrieved July 14, 2006 from http://understandingkatrina.ssrc.org/Hurlbert_Beggs_Haines

Katz, I. (1981). Stigma: A social psychological analysis. Hillsdale, NJ: Erlbaum.

Katz, I., Cohen S., \& Glass, D. (1975). Some determinants of cross-racial helping behavior. Journal of Personality and Social Psychology, 32, 964-970.

Kaufman, S. (2006). The criminalization of New Orleanians in Katrina's wake. Understanding Katrina: Perspectives from the Social Sciences, the Forum of the Social Science Research Council. Retrieved July 14, 2006 from http://understandingkatrina.ssrc.org/Kaufman/

Krause, M. (2006). New Orleans: The public sphere of the disaster. Understanding Katrina: Perspectives from the Social Sciences, the Forum of the Social Science Research Council. Retrieved July 14, 2006 from http://understandingkatrina.ssrc.org/Krause/

Krebs, D. L., Miller, D. T. (1985). Altruism and aggression. In G. Lindzey \& E. Aronson (Eds.), Handbook of Social Psychology (3rd ed., Vol. 2, pp. 1-71). New York: Random House.

Lakoff, A. (2006). From disaster to catastrophe: The limits of preparedness. Understanding Katrina: Perspectives from the Social Sciences, the Forum of the Social Science Research Council. Retrieved July 14, 2006 from http://understandingkatrina.ssrc.org/Lakoff/

Louisiana Department of Health and Hospitals. (2006). Reports of missing and deceased. Retrieved August 2, 2006 from http://www.dhh.louisiana.gov/offices/page.asp?ID=192\&Detail=5248 
Manners, T. (2005). Reveries magazine. Retrieved July 13, 2006 from http://reveries.com/cool_news/ 2005/september/sep_2a.html

Marchetti, S., \& Bunte, S. (2006). Retailers and banks leverage fundraising power, raising more than \$130 million for hurricane relief. Press Room: American Red Cross. Retrieved May 21, 2006 from http://redcross.org/pressrelease/0,1077,0_314_5172,00.html

Molotch, H. (2006). Death on the roof: Race and bureaucratic failure. Understanding Katrina: Perspectives from the Social Sciences, the Forum of the Social Science Research Council. Retrieved July 14, 2006 from http://understandingkatrina.ssrc.org/Molotch/

Neuberg, S. L., Cialdini, R. B., Brown, S. L., Luce, C., Sagarin, B. J., \& Lewis, B. P. (1997). Does empathy lead to anything more than superficial helping? Comment on Batson et al. (1997). Journal of Personality and Social Psychology, 73, 510-516.

Pearce, P. L. (1980). Strangers, travelers, and Greyhound terminals: A study of small-scale helping behavior. Journal of Personality and Social Psychology, 38, 935-940.

Penner, L. A., Dovidio, J. F., Piliavin, J. A., \& Schroeder, D. A. (2005). Prosocial behavior: Multilevel perspectives. Annual Review of Psychology, 56, 365-392.

Perlow, L., \& Weeks, J. (2002). Who's helping whom? Layers of culture and workplace behavior. Journal of Organizational Behavior, 23, 345-361.

Potok, M. (2005). The blame game. Intelligence Report. Retrieved May 21, 2006 from http://splcenter. org/intel/intelreport/article.jsp?aid=558

Rodriguez, H., Trainor, J., \& Quarantelli, E. L. (2006). Rising to the challenges of a catastrophe: The emergent and prosocial behavior following Hurricane Katrina. The Annals of American Academy of Political and Social Science, 604, 82-102.

Ross, L. J. (2005). A feminist perspective on Katrina. Sistersong. Retrieved October 17, 2005 from http://zmag.org/content/showarticle.cfm?SectionID =72\&ItemID=8912

Schwarts, S. H., \& Howard, J. (1981). A normative decision-making model of altruism. In J. P. Rushton, \& R. M. Sorrentino (Eds.), Altruism and helping behavior (pp. 189-211). Hillsdale, NJ: Erlbaum.

Sheppard, D. (2006). Hurricane Katrina's aftermath: The testimony of two eye-witnesses. Hurricane Katrina, 2005: Testimonies of eye-witnesses for students. Retrieved July 11, 2006 from http://www.hurricane-katrina.info/testimonies.html

Staub, E. (1971). Helping a person in distress: The influence of implicit and explicit "rules" of conduct on children and adults. Journal of Personality and Social Psychology, 17, 137-145.

Sue, D. W., \& Sue, D. (1990). Counseling the culturally different: Theory and Practice (2nd Ed.). New York, NY: John Wiley \& Sons.

Thayer, S. (1973). Lend me your ears: Racial and sexual factors in helping the deaf. Journal of Personality and Social Psychology, 28, 8-11.

Wegner, D. M., \& Crano, W. D. (1975). Racial factors in helping behavior: An unobtrusive field experiment. Journal of Personality and Social Psychology, 32, 901-905. British Journal of Social Psychology (2002), 41, 521-534.

Wikipedia: The free encyclopedia. (2005). Hurricane Katrina. Retrieved October 17, 2005 from http://en.wikipedia.org/wiki/Hurricane_Katrina

Wikipedia: The free encyclopedia. (2006). Hurricane Katrina. Retrieved July 14, 2006 from http://en. wikipedia.org/wiki/Hurricane_Katrina

TATYANA V. AVDEYEVA is an assistant professor of Counseling Psychology at the Graduate School of Professional Psychology at the University of St. Thomas in Minneapolis, Minnesota. She holds a doctoral degree in Counseling Psychology from Washington State University, with a pre-doctoral internship completed at the University of Minnesota Counseling and Consulting Services.

KRISTINA BURGETOVA obtained a bachelor's degree in Psychology at Metropolitan State University in Minnesota. She is an intern at a residential facility for 
male juvenile offenders as part of her graduate work at the Graduate School of Professional Psychology at the University of St. Thomas.

I. DAVID WELCH is the dean of the Graduate School of Professional Psychology at the University of St. Thomas in Minneapolis, Minnesota. Dr. Welch is a Diplomat in Counseling Psychology through the American Board of Professional Psychology (ABPP). 